\title{
POTENSI YOGURT TANPA LEMAK DENGAN PENAMBAHAN TEPUNG PISANG DAN TEPUNG GEMBILI SEBAGAI ALTERNATIF MENURUNKAN KOLESTEROL
}

\author{
Ruth Karlin, Arintina Rahayuni*) \\ Program Studi Ilmu Gizi Fakultas Kedokteran Universitas Diponegoro \\ Jl.Dr.Sutomo No.18, Semarang, Telp (024) 8453708, Email : gizifk@undip.ac.id
}

\begin{abstract}
ABSTRAK
Latar Belakang : Hiperkolesterolemia merupakan faktor risiko penyakit kardiovaskuler, yang menjadi penyebab utama kematian di dunia. Yogurt merupakan susu yang difermentasi bakteri asam laktat. dan telah terbukti dapat menurunkan kolesterol. Penambahan prebiotik, seperti FOS dan inulin pada probiotik dapat menunjang efek hipokolesterolemi yogurt. Pisang tanduk (Musa paradisiaca fa. corniculata) merupakan bahan makanan tinggi FOS, sedangkan gembili (Dioscorea esculenta) mengandung tinggi inulin.

Tujuan : Menganalisis pengaruh penambahan tepung pisang dan tepung gembili dalam pembuatan yogurt tanpa lemak terhadap kadar lemak, kadar serat, total BAL, kadar asam propionat, serta karakteristik fisik berupa warna, viskositas, dan $\mathrm{pH}$.

Metode : Penelitian eksperimental dengan rancangan acak lengkap menggunakan 2 variasi penambahan tepung $\left(N_{1}\right.$ dan $N_{2}$ ), yaitu $16.5 \mathrm{~g}$ tepung pisang (mengandung 1\% FOS) dan $13.5 \mathrm{~g}$ tepung gembili (mengandung 2\% inulin), serta 1 kontrol $\left(N_{0}\right)$. Analisis statistik kadar lemak, serat, total bakteri asam laktat, viskositas, dan pH menggunakan uji Kruskal-Wallis CI 99\% dengan uji lanjut Mann-Whitney. Uji kadar asam propionat dan warna hanya dideskripsikan.

Hasil : Perlakuan pada kedua kelompok, memberikan pengaruh yang signifikan pada kadar serat $\left(N_{1}=0.026 \%, N_{2}\right.$ $=0.078 \%)$, total BAL $\left(N_{1}=6.86 \times 10^{8} \mathrm{cfu} / \mathrm{ml}, N_{2}=7.04 \times 10^{7} \mathrm{cfu} / \mathrm{ml}\right)$, viskositas $\left(N_{1}=230.083 \mathrm{cP}, \mathrm{N}_{2}=9.752 \mathrm{cP}\right)$, dan $\mathrm{pH}\left(N_{1}=4.873, N_{2}=5.72\right)$. Kelompok $N_{1}$ memiliki kadar asam propionat tertinggi, yakni sebesar 569.96 ppm dan berwarna yellowish orange, sedangkan $N_{2}$ memiliki kadar asam propionat 52.51 ppm, serta berwarna orangish pink.

Simpulan : Penambahan tepung pisang dan tepung gembili tidak berpengaruh secara signifikan pada kadar lemak, namun penambahan tepung pisang pada yogurt memiliki potensi terbaik untuk menurunkan kolesterol, karena memiliki kadar lemak terendah, total BAL dan kadar asam propionat tertinggi, serta pH paling mendekati pH optimal.
\end{abstract}

Kata Kunci : yogurt; prebiotik; fruktooligosakarida; inulin; kolesterol

\begin{abstract}
Background : Hypercholesterolemia is one of the risk factor for cardiovascular disease, which becomes as one of the main cause of death in the world. Yogurt is a fermented milk product, produced by lactic acid bacteria and has been proved to lower cholesterol. The addition of prebiotic, like FOS and inulin into probiotic can support hypocholesterolemic effect on yogurt. Plantain (Musa paradisiaca fa. Corniculata) contains a high FOS, whereas lesser yam (Dioscorea esculenta) high in inulin.

Objective : To analyze the effect of the addition of plantain and lesser yam flour in the production of nonfat yogurt on the fat content, fiber content, total of lactic acid bacteria (LAB), propionic acid levels, as well as physical characteristic, defined as color, viscosity, and $\mathrm{pH}$.

Methods : A randomized experimental design using two variations of the addition of flour $\left(N_{1}\right.$ and $\left.N_{2}\right)$, i.e. $16.5 \mathrm{~g}$ plantain flour (containing $1 \%$ of FOS) and $13.5 \mathrm{~g}$ of lesser yam flour (containing $2 \%$ of inulin) and 1 control $\left(N_{0}\right)$. Statistical analysis of fat content, fiber, total of LAB, viscosity, and pH analyzed using the Kruskal-Wallis test, with 99\% CI, and post hoc test using Mann-Whitney afterwards. Propionic acid level tests and colors are just described. Results :The treatment in both groups gives out a significant influence on the fiber content $\left(N_{1}=0.026 \%, N_{2}=\right.$ $0.078 \%)$, total of $L A B\left(N_{1}=6.86 \times 10^{8} \mathrm{cfu} / \mathrm{ml}, N_{2}=7.04 \times 10^{7} \mathrm{cfu} / \mathrm{ml}\right)$, viscosity $\left(N_{1}=230.083 \mathrm{cP}, \mathrm{N}_{2}=9.752 \mathrm{cP}\right)$, and $\mathrm{pH}\left(N_{1}=4.873, N_{2}=5.72\right) . N_{1}$ group has the highest levels of propionic acid, which is equal to $569.96 \mathrm{ppm}$ and has yellowish orange as the color, while the $N_{2}$ has a 52.51 ppm propionic acid levels and colored orangish pink.

Conclusion : The addition of plantain and lesser yam flours doesn't generate a significant effect on fat content, but the addition of plantain flour in of yogurt has the best potential to lower cholesterol, because it has the lowest fat content, the highest total of LAB and propionic acid levels, and the most optimal $\mathrm{pH}$.
\end{abstract}

Keywords : yogurt; prebiotic; fructooligosaccharide; inulin; cholesterol 


\section{PENDAHULUAN}

Menurut WHO, penyakit kardiovaskuler merupakan penyebab utama kematian di dunia. Pada tahun 2004 terdapat sekitar 17.1 juta orang di dunia meninggal karena penyakit kardiovaskuler. Prediksi WHO di tahun 2030, penyakit kardiovaskuler dapat menyebabkan kematian sekitar 23.6 juta orang di dunia. ${ }^{1}$ Faktor risiko utama terjadinya penyakit kardiovaskuler adalah tingginya kadar kolesterol darah (hiperkolesterolemia), yang dapat menyebabkan pembentukan plak di dinding pembuluh darah (aterosklerosis) dan menyebabkan risiko serangan jantung tiga kali lebih besar. Penurunan 1\% kolesterol darah dapat mengurangi 2-3\% risiko penyakit jantung koroner (sumbatan di pembuluh koroner jantung). ${ }^{2}$

Prinsip penggunaan bakteri asam laktat, telah lama dipercaya sebagai cara alami untuk menurunkan kadar kolesterol darah pada manusia. ${ }^{3}$ Yogurt merupakan salah satu produk olahan susu yang difermentasi menggunakan bakteri asam laktat, dengan atau tanpa penambahan bahan pangan lain dan bahan tambahan pangan yang diizinkan. ${ }^{4}$ Lactobacillus bulgaricus dan Streptococcus thermophilus merupakan dua jenis bakteri standar yang digunakan dalam pembuatan yogurt. ${ }^{5}$ Penggunaan susu tanpa lemak sebagai bahan dasar pembuatan yogurt akan meminimalkan kadar lemak pada hasil akhir.

Umumnya yogurt yang dijual di pasaran merupakan yogurt probiotik. Probiotik didefinisikan sebagai mikroorganisme hidup yang bila dalam jumlah yang cukup dapat memberikan efek kesehatan bagi tubuh. ${ }^{6}$ Salah satu efek kesehatannya dapat menurunkan kolesterol. Di sisi lain, terdapat jenis yogurt sinbiotik, yakni yogurt probiotik dengan tambahan prebiotik. ${ }^{7}$ Prebiotik merupakan bahan makanan terfermentasi secara selektif yang memberikan perubahan spesifik, baik pada komposisi dan/atau aktivitas mikrobiota gastrointestinal, yang memberi keuntungan terhadap keadaan dan kesehatan tubuh. ${ }^{8}$ Penelitian pada hewan menunjukkan penurunan kolesterol dan/atau trigliserida sehubungan dengan konsumsi prebiotik. $^{9,10}$ Prebiotik mengurangi absorpsi kolesterol dengan memacu ekskresinya melalui feses, dan memproduksi asam lemak rantai pendek (short-chain fatty acids/SCFAs), terutama asam propionat yang dapat menghambat sintesis asam lemak dan kolesterol di hati, sehingga menurunkan kadar kolesterol darah. ${ }^{11-13}$ Di samping itu, bukti percobaan pada manusia, hewan, dan in vitro membuktikan bahwa prebiotik dapat meningkatkan jumlah mikroflora usus, seperti lactobacilli. ${ }^{8}$

Frukto-oligosakarida (FOS) dan inulin merupakan jenis prebiotik yang banyak diteliti sehubungan dengan manfaat kesehatan. FOS termasuk golongan oligosakarida tak tercerna, sehingga digolongkan sebagai serat pangan. Di Indonesia, sumber FOS yang relatif tinggi dan mudah ditemui adalah pisang. Secara umum, terkandung $2 \mathrm{mg} / \mathrm{g}$ FOS pisang matang. ${ }^{14}$ Penambahan $1 \%$ FOS pada yogurt dapat meningkatkan jumlah bakteri asam laktat (Streptococcus thermophilus, Lactobacillus acidophilus, dan Bifidobacterium sp.). ${ }^{15}$

Selain FOS, inulin juga termasuk serat pangan larut air, yang difermentasi di usus menghasilkan SCFAs. ${ }^{16}$ Sebagai fungsi serat, inulin mengurangi absorpsi lemak dan mengurangi kadar kolesterol darah. ${ }^{17,18}$ Bahan makanan tinggi inulin yang produksinya melimpah di Indonesia adalah umbi gembili (Dioscorea esculenta). Dibandingkan dengan semua jenis umbi, gembili memiliki kadar inulin tertinggi, dengan $14.77 \%$ berat keringnya. ${ }^{19}$ Pemberian $18 \mathrm{~g}$ inulin per hari pada pria dan wanita hiperkolesterolemia, dapat menurunkan kadar total kolesterol darah secara signifikan, sebanyak $8.7 \% .^{20}$ Penambahan $2 \%$ inulin dalam yogurt sinbiotik yang mengandung $L$. acidophilus dan $L$. casei dapat meningkatkan bakteri probiotik dan kualitas organoleptik. ${ }^{21,22}$

Yogurt tanpa lemak dengan penambahan prebiotik dapat menjadi pangan alternatif yang berpotensi menurunkan kolesterol. Oleh karena itu, penelitian ini diperlukan untuk menganalisis pengaruh penambahan tepung pisang dan tepung gembili dalam pembuatan yogurt tanpa lemak terhadap kadar lemak, kadar serat, total BAL, kadar asam propionat, serta karakteristik fisik berupa warna, viskositas, dan $\mathrm{pH}$.

\section{METODE}

Penelitian yang dilakukan merupakan penelitian di bidang produksi makanan. Penelitian ini merupakan penelitian eksperimental dengan rancangan acak lengkap menggunakan penambahan dua jenis prebiotik, tepung pisang sebagai sumber FOS (perlakuan 1) dan tepung gembili sebagai sumber inulin (perlakuan 2) dan satu kontrol (tanpa penambahan prebiotik) $(\mathrm{t}=3)$, yang disimbolkan dengan $\mathrm{N}_{1}, \mathrm{~N}_{2}$, dan $\mathrm{N}_{0}$. Setiap kelompok perlakuan dilakukan pengulangan sebanyak tiga kali.

Subjek dalam penelitian ini adalah yogurt sinbiotik tanpa lemak yang terbuat dari fermentasi 
susu skim/tanpa lemak sebagai bahan utama, oleh Lactobacillus bulgaricus dan Streptococcus thermophilus, dengan penambahan $16.5 \mathrm{~g}$ tepung pisang sebagai sumber FOS dan $13.5 \mathrm{~g}$ tepung gembili sebagai sumber inulin. Bahan-bahan yang digunakan dalam pembuatan yogurt sinbiotik tanpa lemak adalah susu skim/tanpa lemak segar, susu bubuk skim, inokulum murni Lactobacillus bulgaricus dan Streptococcus thermophilus dari Laboratorium Bioteknologi, Fakultas Teknologi Pertanian, Universitas Gadjah Mada, Yogyakarta, tepung pisang dan tepung gembili yang dibuat oleh peneliti.

Tepung pisang dibuat dari pisang tanduk (Musa paradisiaca fa. corniculata) dan tepung gembili dibuat dari umbi gembili (Dioscorea esculenta). Pembuatan tepung menggunakan prinsip perendaman dalam larutan natrium metabisulfit selama 10 menit, pengeringan menggunakan oven, dihaluskan, dan diayak melewati ayakan 80 mesh. Pada penelitian pendahuluan, dilakukan uji kadar FOS pada tepung pisang, dengan menggunakan HPLC, yang dilakukan di Laboratorium Penelitian dan Pengujian Terpadu, Universitas Gadjah Mada, Yogyakarta. Proses fermentasi yogurt oleh Lactobacillus bulgaricus dan Streptococcus thermophilus dilakukan selama 12 jam pada suhu $43^{\circ} \mathrm{C}$, setelah dilakukan pasteurisasi selama 10 menit pada suhu $90^{\circ} \mathrm{C}$.

Uji kadar lemak, kadar serat, total bakteri asam laktat, kadar asam propionat, warna, viskositas, dan pH. Kadar lemak diukur menggunakan metode Majonnier, ${ }^{4}$ kadar serat menggunakan metode gravimetri, total bakteri asam laktat menggunakan TPC (Total Plate Count) dengan media MRS (De Man Rogosa and
Sharpe),${ }^{4}$ dan kadar asam propionat menggunakan HPLC. Untuk mengetahui karakteristik fisik, berupa uji warna dapat dilakukan dengan alat kromameter, konsistensi dengan viscotester, dan untuk mengetahui $\mathrm{pH}$ dengan $\mathrm{pH}$ meter. Analisis kadar lemak dan serat dilakukan di Laboratorium Pangan dan Gizi, uji total bakteri asam laktat dilakukan di Laboratorium Bioteknologi, dan uji warna, viskositas, serta $\mathrm{pH}$ diuji di Laboratorium Rekayasa Pangan dan Hasil Pertanian Fakultas Teknologi Pertanian, Universitas Gadjah Mada, Yogyakarta. Uji kadar asam propionat dilakukan di Laboratorium Penelitian dan Pengujian Terpadu, Universitas Gadjah Mada, Yogyakarta.

Pengaruh penambahan prebiotik terhadap kadar asam propionat dan karakteristik fisik (warna, viskositas, dan $\mathrm{pH}$ ) hanya dideskripsikan, sedangkan kadar lemak, kadar serat, dan total bakteri asam laktat, diolah menggunakan uji statistik Kruskal-Wallis, karena data berdistribusi tidak normal. Uji dilakukan dengan derajat kepercayaan 99\%, dan dilanjutkan dengan uji posthoc Mann-Whitney untuk mengetahui beda nyata antar kelompok perlakuan dan kontrol.

\section{HASIL}

1. Kadar Lemak

Kadar lemak yogurt diukur dengan menggunakan metode Majonnier. Yogurt pada kelompok kontrol memiliki nilai ratarata kadar lemak tertinggi, sedangkan yogurt dengan penambahan tepung pisang memiliki nilai rata-rata kadar lemak terendah. Hasil uji statistik Kruskal-Wallis menyatakan bahwa tidak ada pengaruh penambahan prebiotik terhadap kadar lemak yogurt sinbiotik tanpa lemak (Lampiran 3).

Tabel 1. Hasil Analisis Kadar Lemak Yogurt Sinbiotik Tanpa Lemak

\begin{tabular}{cc}
\hline Perlakuan & Kadar Lemak (\%) \\
\hline $\mathrm{N}_{0}$ (kontrol) & $0.48 \pm 0.07$ \\
$\mathrm{~N}_{1}$ (penambahan tepung pisang) & $0.41 \pm 0.032$ \\
$\mathrm{~N}_{2}$ (penambahan tepung gembili) & $0.42 \pm 0.04$ \\
\hline & $\mathrm{P}=0.142$
\end{tabular}

Uji Kruskal-Wallis. Uji post-hoc Mann Whitney; $\mathrm{N}_{0}$ memiliki perbedaan bermakna dengan $\mathrm{N}_{1}$ dan $\mathrm{N}_{2} ; \mathrm{N}_{1}$ memiliki perbedaan bermakna dengan kelompok perlakuan $\mathrm{N}_{2}$.

\section{Kadar Serat}

Kadar serat yogurt sinbiotik tanpa lemak diukur dengan menggunakan metode gravimetri. Yogurt pada kelompok kontrol memiliki nilai rata-rata kadar serat terendah, sedangkan yogurt dengan penambahan tepung gembili memiliki nilai rata-rata kadar serat tertinggi. Hasil uji statistik Kruskal-Wallis menyatakan ada pengaruh penambahan prebiotik terhadap kadar serat yogurt sinbiotik tanpa lemak (Lampiran 5). 
Tabel 2. Hasil Analisis Kadar Serat Yogurt Sinbiotik Tanpa Lemak

\begin{tabular}{cc}
\hline Perlakuan & Kadar Serat (\%) \\
\hline $\mathrm{N}_{0}$ (kontrol) & $0 \pm 0$ \\
$\mathrm{~N}_{1}$ (penambahan tepung pisang) & $0.03 \pm 0.02$ \\
$\mathrm{~N}_{2}$ (penambahan tepung gembili) & $0.08 \pm 0.01$ \\
\hline & $\mathrm{P}=0.000$ \\
\hline
\end{tabular}

Uji Kruskal-Wallis. Uji post-hoc Mann Whitney; $\mathrm{N}_{0}$ memiliki perbedaan bermakna dengan $\mathrm{N}_{1}$ dan $\mathrm{N}_{2} ; \mathrm{N}_{1}$ memiliki perbedaan bermakna dengan kelompok perlakuan $\mathrm{N}_{2}$.

3. Total Bakteri Asam Laktat (BAL)

Total bakteri asam laktat diukur dengan menggunakan total plate count. Yogurt pada kelompok dengan penambahan tepung pisang memiliki nilai rata-rata total BAL tertinggi, sedangkan yogurt pada kelompok kontrol memiliki nilai rata-rata total BAL terendah. Hasil uji statistik Kruskal-Wallis menyatakan ada pengaruh penambahan prebiotik terhadap total bakteri asam laktat yogurt sinbiotik tanpa lemak (Lampiran 7).

Tabel 3. Hasil Analisis Total BAL Yogurt Sinbiotik Tanpa Lemak

\begin{tabular}{cc}
\hline Perlakuan & Total BAL $(\mathbf{c f u} / \mathbf{m l})$ \\
\hline $\mathrm{N}_{0}$ (kontrol) & $1.22 \pm 5.11 \times 10^{7}$ \\
$\mathrm{~N}_{1}$ (penambahan tepung pisang) & $0.69 \pm 2.97 \times 10^{9}$ \\
$\mathrm{~N}_{2}$ (penambahan tepung gembili) & $0.7 \pm 6.52 \times 10^{8}$ \\
\hline & $\mathrm{P}=0.001$ \\
\hline
\end{tabular}

Uji Kruskal-Wallis. Uji post-hoc Mann Whitney; $\mathrm{N}_{0}$ memiliki perbedaan bermakna dengan $\mathrm{N}_{1}$ dan $\mathrm{N}_{2} ; \mathrm{N}_{1}$ memiliki perbedaan bermakna dengan kelompok perlakuan $\mathrm{N}_{2}$.

4. Kadar Asam Propionat

Data kadar asam propionat diukur dengan menggunakan HPLC. Yogurt pada kelompok kontrol memiliki kadar asam propionat terendah, yaitu $<2.6 \mathrm{ppm}$. Yogurt dengan penambahan tepung pisang memiliki kadar asam propionat tertinggi, yaitu 569.96 ppm, sedangkan pada kelompok perlakuan dengan penambahan tepung gembili diperoleh hasil $52.51 \mathrm{ppm}$.

5. Karakteristik Fisik

a. Warna

Uji warna menggunakan alat kromameter, kemudian hasil diinterpretasikan ke dalam warna menggunakan CIE Chromaticity Diagram (Lampiran 10). Yogurt pada kelompok kontrol memiliki warna white light, pada kelompok dengan penambahan tepung gembili berwarna orangish pink, dan pada kelompok dengan penambahan tepung pisang berwarna yellowish orange.

b. Viskositas

Hasil uji viskositas diperoleh dengan menggunakan alat viscotester. Semakin besar hasil keluaran uji, semakin besar tingkat kekentalan yogurt tersebut. Yogurt pada kelompok kontrol memiliki nilai rata-rata viskositas terendah, sedangkan yogurt dengan penambahan tepung pisang memiliki nilai rata-rata viskositas tertinggi. Hasil uji statistik Kruskal-Wallis menyatakan ada pengaruh penambahan prebiotik terhadap viskositas yogurt sinbiotik tanpa lemak (Lampiran $10)$.

Tabel 4. Hasil Analisis Viskositas Yogurt Sinbiotik Tanpa Lemak

\begin{tabular}{cc}
\hline Perlakuan & Viskositas $(\mathbf{c P})$ \\
\hline $\mathrm{N}_{0}$ (kontrol) & $7.01 \pm 1.48$ \\
$\mathrm{~N}_{1}$ (penambahan tepung pisang) & $230.08 \pm 15.21$ \\
$\mathrm{~N}_{2}$ (penambahan tepung gembili) & $9.75 \pm 0.73$ \\
\hline & $\mathrm{P}=0.000$ \\
\hline
\end{tabular}

Uji Kruskal-Wallis. Uji post-hoc Mann Whitney; $\mathrm{N}_{0}$ memiliki perbedaan bermakna dengan $\mathrm{N}_{1}$ dan $\mathrm{N}_{2} ; \mathrm{N}_{1}$ memiliki perbedaan bermakna dengan kelompok perlakuan $\mathrm{N}_{2}$.

b. $\mathrm{pH}$ 


\begin{abstract}
Data hasil pengukuran menggunakan pHmeter menunjukkan yogurt pada kelompok kontrol memiliki nilai rata-rata $\mathrm{pH}$ terendah. Yogurt dengan penambahan tepung gembili memiliki nilai
\end{abstract}

rata-rata $\mathrm{pH}$ tertinggi. Hasil uji statistik Kruskal-Wallis menyatakan ada pengaruh penambahan prebiotik terhadap $\mathrm{pH}$ yogurt sinbiotik tanpa lemak (Lampiran 13).

Tabel 5. Hasil Analisis pH Yogurt Sinbiotik Tanpa Lemak

\begin{tabular}{cc}
\hline Perlakuan & pH \\
\hline $\mathrm{N}_{0}$ (kontrol) & $4.23 \pm 0$ \\
$\mathrm{~N}_{1}$ (penambahan tepung pisang) & $4.87 \pm 0.12$ \\
$\mathrm{~N}_{2}$ (penambahan tepung gembili) & $5.72 \pm 0.5$ \\
\hline & $\mathrm{P}=0.000$
\end{tabular}

Uji Kruskal-Wallis. Uji post-hoc Mann Whitney; $\mathrm{N}_{0}$ memiliki perbedaan bermakna dengan $\mathrm{N}_{1}$ dan $\mathrm{N}_{2} ; \mathrm{N}_{1}$ memiliki perbedaan bermakna dengan kelompok perlakuan $\mathrm{N}_{2}$.

\section{PEMBAHASAN}

\section{Kadar Lemak}

Yogurt bersifat hipokolesterolemik, dan jika dikonsumsi dalam jumlah tertentu dapat menurunkan kadar kolesterol pada serum darah manusia. Kadar lemak yang rendah dalam yogurt dengan penggunaan susu tanpa lemak, sehingga dapat menunjang sifat hipokolesterolemik. ${ }^{23}$

SNI membedakan jenis yogurt, salah satunya berdasarkan kadar lemak yang terkandung di dalamnya. Yogurt tanpa lemak (non fat) seharusnya memiliki kadar lemak susu kurang dari $0.5 \% .^{4}$ Data yang diperoleh dalam penelitian, menyatakan bahwa yogurt pada kelompok kontrol dan perlakuan memiliki kadar lemak di bawah 0.5\%. Semua kelompok yogurt memenuhi syarat kadar lemak SNI untuk yogurt tanpa lemak.

Susu segar tanpa lemak dan susu bubuk skim yang dijadikan bahan utama pembuatan yogurt, dapat menghasilkan kadar lemak pada produk akhir di bawah $0.5 \%$. Penambahan tepung pisang dan tepung gembili tidak mempengaruhi kadar lemak yogurt. Kadar lemak terendah terdapat pada kelompok dengan penambahan tepung pisang, yakni sebesar $0.41 \%$. Kadar lemak tertinggi terdapat pada kelompok kontrol, yakni sebesar $0.48 \%$, namun perbedaan antar kelompok perlakuan dan kontrol tidak signifikan. Penambahan tepung pisang dan tepung gembili menambah volume yogurt yang dihasilkan dibandingkan dengan yogurt pada kelompok kontrol. Hal tersebut memungkinkan konsentrasi lemak per $\mathrm{ml}$ sampel yang dianalisis pada kelompok perlakuan menjadi lebih sedikit dibandingkan kelompok kontrol yang lebih pekat.

2. Kadar Serat
Penentuan kadar serat pada penelitian ini menggunakan metode gravimetri, yakni dengan prinsip degradasi asam basa. Gravimetri memiliki kelemahan, yaitu memerlukan waktu yang relatif lama dan hanya dapat digunakan untuk mengukur kadar pada komponen yang cukup besar, terutama serat kasar. FOS dan inulin merupakan serat pangan yang tergolong dalam serat larut air. Penentuan kadar serat larut air lebih sensitif jika menggunakan analisis dengan prinsip enzimatis, ${ }^{24}$ namun karena keterbatasan biaya, maka dalam penelitian ini menggunakan metode gravimetri yang lebih murah.

Penggunaan metode gravimetri menyebabkan kadar serat yang dihitung hanya terdeteksi dalam jumlah kecil pada kelompok dengan penambahan prebiotik, bahkan $0 \%$ pada yogurt kelompok kontrol. Data penelitian menunjukkan, yogurt dengan penambahan tepung gembili memiliki kadar serat tertinggi, yakni sejumlah $0.08 \%$, sedangkan kelompok sampel dengan penambahan tepung pisang memiliki kadar serat sebesar $0.03 \%$. Berdasarkan penelitian pendahuluan, tepung pisang tanduk (Musa paradisiaca fa. corniculata) yang digunakan dalam penelitian, memiliki kadar FOS sebesar 6.08\%. Kadar inulin yang terkandung dalam tepung gembili sebesar $14.77 \% .^{25}$ Perbedaan kadar prebiotik yang terkandung dalam masing-masing tepung mempengaruhi hasil analisis secara statistik, sehingga menunjukkan perbedaan yang signifikan baik antar kelompok perlakuan dan kontrol, maupun antar kelompok perlakuan.

FOS yang terkandung dalam tepung pisang dan inulin yang terkandung dalam tepung gembili tidak hanya memiliki fungsi serat sebagai agen hipokolesterol, namun juga 
berfungsi sebagai prebiotik di kolon. Adanya prebiotik dapat meningkatkan jumlah mikroflora usus, melalui mekanisme fermentasi dan menciptakan suasana asam yang menjadi faktor penunjang pertumbuhan mikroflora. ${ }^{26}$

\section{Total Bakteri Asam Laktat (BAL)}

Jumlah bakteri asam laktat (BAL) yang dihitung dalam penelitian ini, terdiri dari Lactobacillus bulgaricus dan Streptococcus thermophilus. Banyaknya BAL yang terkandung dalam yogurt dapat dipengaruhi oleh beberapa faktor, seperti komponen media tumbuh, suhu saat inokulasi, lama fermentasi, lama penyimpanan, suhu penyimpanan, kandungan nutrisi substrat, dan $\mathrm{pH}$. BAL memerlukan beberapa zat gizi untuk tumbuh, terutama sumber nitrogen. Sumber nitrogen umumnya diperoleh dari asam amino atau peptida yang dihasilkan dari proses proteolisis. ${ }^{27}$ Tepung pisang mengandung $3.8-$ $4.1 \%$ protein, ${ }^{28}$ sedangkan gembili mengandung $7.4 \%$ protein. ${ }^{29}$ Oleh karena itu, total BAL pada kelompok perlakuan lebih tinggi dibandingkan kelompok kontrol.

Di sisi lain, penambahan FOS dan inulin pada yogurt juga dapat meningkatkan jumlah BAL dibandingkan yogurt pada kelompok kontrol. ${ }^{30}$ Penambahan $1 \%$ FOS pada yogurt dapat meningkatkan jumlah bakteri asam laktat, sedangkan penambahan 2 dan 3\% FOS secara signifikan mengurangi jumlah bakteri asam laktat selama penyimpanan dingin. ${ }^{31,} 32$ Penambahan $2 \%$ inulin dalam yogurt, menghasilkan hasil organoleptik yang paling disukai panelis dan dapat meningkatkan bakteri probiotik. ${ }^{33}$ Pada penelitian ini, jumlah BAL paling banyak ditemukan pada yogurt dengan penambahan tepung pisang (sumber FOS). Terdapat perbedaan yang signifikan, baik antar kelompok perlakuan, maupun antara kelompok kontrol dan kelompok perlakuan.

Masing-masing kultur yang digunakan untuk proses fermentasi yogurt memiliki suhu dan $\mathrm{pH}$ optimum, yang akan menentukan pertumbuhan bakteri tersebut. Saat kedua bakteri difermentasikan bersama, Lactobacillus bulgaricus memulai fermentasi terlebih dahulu, dan memproduksi asam amino yang mendukung pertumbuhan Streptococcus thermophilus, kemudian bakteri ini akan melanjutkan fermentasi dengan cepat untuk memproduksi asam laktat dari laktosa hingga pH mencapai sekitar 5.0. Sejalan dengan pertumbuhannya, bakteri ini melepaskan substansi (karbondioksida dan asam format) yang menunjang pertumbuhan Lactobacillus bulgaricus. Peningkatan jumlah Lactobacillus bulgaricus menyebabkan penurunan $\mathrm{pH}$. Pertumbuhan Streptococcus thermophilus semakin menurun karena lebih tidak tahan terhadap asam. ${ }^{34}$ Lactobacillus bulgaricus akan tumbuh optimal pada suhu $42-45^{\circ} \mathrm{C}$ dan $\mathrm{pH}$ berkisar antara $5.4-4.6$, dengan produksi asam laktat $1.5-4 \%$. Streptococcus thermophillus akan tumbuh optimal pada suhu $45^{\circ} \mathrm{C}$ dan berhenti tumbuh pada $\mathrm{pH} 4.2$, dengan produksi asam laktat $0.8-1 \%$. ${ }^{35,36}$

SNI menetapkan jumlah BAL minimal pada yogurt adalah $10^{7} \mathrm{cfu} / \mathrm{ml}{ }^{4} \quad$ Semua kelompok yogurt, baik kontrol dan perlakuan memenuhi syarat minimal total BAL SNI. Total BAL terendah terdapat pada yogurt kelompok kontrol, yakni sebesar $1.22 \times 10^{7} \mathrm{cfu} / \mathrm{ml}$ dan total BAL terbanyak terdapat pada kelompok yogurt dengan penambahan tepung pisang, yaitu sebesar 6.87 x $10^{8} \mathrm{cfu} / \mathrm{ml}$. Kelompok yogurt dengan penambahan tepung gembili memiliki total BAL $7.04 \times 10^{7} \mathrm{cfu} / \mathrm{ml}$.

Keberadaan prebiotik dapat memperbaiki mikroflora usus, dengan meningkatkan pertumbuhan probiotik. ${ }^{37}$ Penurunan kadar kolesterol oleh adanya probiotik, dapat melalui beberapa mekanisme. Dekonjugasi asam empedu oleh enzim Bile-Salt Hydrolase (BSH) yang dihasilkan probiotik, sehingga asam empedu kurang larut dan kurang diserap di saluran cerna, dan dieliminasi melalui feses. Pada respon homeostasis, kolesterol digunakan untuk sintesis asam empedu baru, sehingga menurunkan kadar kolesterol. Efek hipokolesterolemi juga dapat melalui asimilasi kolesterol dan membran sel probiotik selama pertumbuhan. Kolesterol juga dapat dikonversi menjadi koprostanol oleh probiotik, yang secara langsung diekskresikan feses. ${ }^{38}$

4. Kadar Asam Propionat

FOS dan inulin sebagai prebiotik, selain untuk meningkatkan pertumbuhan probiotik, juga untuk memproduksi asam lemak rantai pendek (SCFA/short-chain fatty acid). Asam propionat merupakan salah satu SCFA hasil fermentasi prebiotik yang dimetabolisme di hati. Asam propionat dapat menurunkan konsentrasi kolesterol darah, dengan mencegah kolesterogenesis hepatik (sintesis kolesterol di hati). ${ }^{39,40}$ 
Sebuah penelitian menyatakan, FOS menghasilkan total SCFA tertinggi saat terfermentasi di saluran cerna manusia, dibanding dengan galaktooligosakarida (GOS), mananoligosakarida (MOS), dan chitooligosakarida $(\mathrm{COS}){ }^{41}$ Penelitian lain mengatakan, SCFA yang paling banyak dihasilkan dari proses fermentasi inulin umbi gembili adalah asam asetat, propionat dan butirat. Hal ini terjadi karena terjadi pemecahan polisakarida, yang kemudian dihidrolisis lebih lanjut. ${ }^{42}$ Hasil penelitian menyatakan, yogurt dengan penambahan tepung pisang (FOS) memiliki kadar asam propionat tertinggi, yaitu 569.96 ppm. Yogurt dengan penambahan tepung gembili (inulin) memiliki kadar asam propionat $52.51 \mathrm{ppm}$, sedangkan kelompok kontrol memiliki kadar asam propionat terendah, yaitu $<2.6 \mathrm{ppm}$.

5. Karakteristik Fisik

a. Warna

Hasil uji analisis warna menunjukkan bahwa terdapat perbedaan warna antara kelompok kontrol dan perlakuan. Pada umumnya yogurt tanpa penambahan pewarna makanan tertentu akan berwarna putih. Yogurt pada kelompok kontrol memiliki warna white light, sedangkan pada kelompok dengan penambahan tepung pisang berwarna yellowish orange. Yogurt dengan penambahan tepung pisang berwarna lebih gelap. Hal tersebut terjadi karena reaksi browning secara enzimatis, yakni perubahan warna, sebagai hasil dari polyphenol oxidase (PPO) yang terpapar oksigen, kemudian teroksidasi menjadi kuinon. Kuinon terkondensasi dan bereaksi secara nonenzimatis dengan komponen fenol lain dan asam amino, sehingga menghasilkan warna kecoklatan. ${ }^{43}$

Yogurt pada kelompok dengan penambahan tepung gembili berwarna orangish sedikit lebih gelap dibandingkan kelompok kontrol. Menurut penelitian, gembili (Dioscorea esculenta) mengandung $\alpha$-karoten dan $\beta$-karoten. Hal tersebut memungkinkan yogurt dengan penambahan tepung gembili berwarna sedikit oranye. ${ }^{44}$ Pada penelitian ini, belum dilakukan uji penerimaan terhadap perbedaan warna yogurt dengan penambahan tepung pisang dan tepung gembili.

b. Viskositas
Tingkat kekentalan yogurt dapat dipengaruhi oleh beberapa faktor, seperti bahan utama penyusun yogurt (jenis susu) dan lama penyimpanan. ${ }^{45}$ Di samping itu, penambahan serat dapat mempengaruhi tekstur dan konsistensi produk yang dihasilkan. ${ }^{46}$ Sebuah penelitian menunjukkan, penambahan inulin dapat membantu meningkatkan kekentalan pada produk fermentasi. ${ }^{47}$ Konsistensi yogurt dengan penambahan FOS dan inulin meningkat selama masa penyimpanan 21 hari dalam lemari pendingin. ${ }^{30}$

Hasil uji viskositas dinyatakan dalam satuan cP (centi poise). Semakin besar nilai yang dihasilkan, berarti sampel yang diuji semakin kental atau viscous, sebaliknya, jika semakin kecil nilai yang dihasilkan, sampel yang diuji semakin cair atau encer. Data hasil penelitian menunjukkan bahwa kelompok yogurt dengan penambahan tepung pisang memiliki nilai viskositas tertinggi, dengan nilai rata-rata sebesar 230.08 cP, sedangkan kelompok dengan penambahan tepung gembili memiliki nilai viskositas sebesar $9.75 \mathrm{cP}$.

Pisang tanduk mengandung kadar pati (37\%) relatif tinggi dibanding jenis pisang lain. Sebuah penelitian menunjukkan, kadar pati yang terkandung dalam gembili sebesar $23.25 \%{ }^{48}$ Penambahan $3 \%$ pati pada pembuatan yogurt dapat meningkatkan viskositas secara signifikan. ${ }^{49}$ Hal tersebut dapat terjadi karena adanya gelatinisasi pati. Proses gelatinisasi pati terjadi saat air diserap ke dalam sel, sehingga terjadi pembengkakkan dengan adanya pemanasan. Air di dalam sel terikat kuat oleh struktur heliks ganda, dan menyebabkan pembengkakkan tersebut bersifat irreversible. $^{50}$

Nilai viskositas terendah berada pada kelompok kontrol, dengan nilai rata-rata sebesar $7.01 \mathrm{cP}$, yang mendekati viskositas yogurt pada umumnya. Di sisi lain, viskositas pada kelompok dengan penambahan tepung pisang terlalu kental untuk dikonsumsi, sehingga dapat dilakukan pengenceran. Pengenceran dapat dilakukan sebanyak \pm 32 kali untuk mendapatkan viskositas mendekati kelompok kontrol, dengan total BAL $2.15 \times 10^{7} \mathrm{cfu} / \mathrm{ml}$ (memenuhi standar SNI untuk total BAL).

c. $\mathrm{pH}$ 
Pada penelitian ini, tingkat keasaman yogurt dinyatakan dalam $\mathrm{pH}$. Total bakteri asam laktat dan $\mathrm{pH}$ pada yogurt dapat saling mempengaruhi dan berkaitan. Yogurt pada umumnya memiliki $\mathrm{pH} 4.6 .^{51}$ Data hasil penelitian, menunjukkan $\mathrm{pH}$ pada kelompok kontrol memiliki nilai terendah, yaitu sebesar 4.23. Hal tersebut dapat dikaitkan dengan nutrisi yang terkandung dalam substrat.

BAL memerlukan sumber nitrogen untuk tumbuh. Sumber nitrogen umumnya diperoleh dari asam amino atau peptida yang dihasilkan dari proses proteolisis. ${ }^{28}$ Seperti telah dijelaskan sebelumnya, penambahan tepung pisang dan tepung gembili akan meningkatkan kadar protein dalam substrat. Proses proteolisis oleh BAL akan menghasilkan asam amino, yang bersifat amfoterik (menjadi asam pada larutan basa dan menjadi basa dalam larutan asam) ${ }^{52}$ Oleh karena itu, yogurt pada kedua kelompok perlakuan memiliki $\mathrm{pH}$ lebih tinggi dan memiliki total BAL lebih banyak, karena masih dalam $\mathrm{pH}$ optimal pertumbuhan BAL dibandingkan dengan kelompok kontrol.

\section{SIMPULAN}

1. Kedua kelompok perlakuan memenuhi syarat kadar lemak SNI untuk yogurt tanpa lemak $(<0.5 \%)$. Yogurt dengan penambahan tepung pisang, memiliki kadar lemak terendah, yaitu $0.41 \%$. Yogurt dengan penambahan tepung gembili memiliki kadar serat tertinggi, yaitu $0.08 \%$. Yogurt dengan penambahan tepung pisang memiliki kadar asam propionat tertinggi, yaitu 569.96 ppm.

2. Kedua kelompok perlakuan memenuhi syarat total BAL SNI (minimal $10^{7} \mathrm{cfu} / \mathrm{ml}$ ). Yogurt dengan penambahan tepung pisang memiliki total bakteri asam laktat tertinggi, yaitu $6.87 \mathrm{x}$ $10^{8} \mathrm{cfu} / \mathrm{ml}$, dengan $\mathrm{pH} 4.87$.

3. Yogurt dengan penambahan tepung gembili memberi warna orangish pink, dan pada kelompok dengan penambahan tepung pisang berwarna yellowish orange. Yogurt dengan penambahan tepung pisang memiliki viskositas tertinggi, yaitu $230.08 \mathrm{cP}$.

\section{SARAN}

1. Hasil penelitian merekomendasikan yogurt sinbiotik tanpa lemak dengan penambahan tepung pisang, karena memiliki potensi menurunkan kolesterol paling optimal dibandingkan kelompok kontrol dan kelompok dengan penambahan tepung gembili, yakni dengan kadar lemak terendah, total bakteri asam laktat tertinggi, kadar asam propionat tertinggi, dan berada pada $\mathrm{pH}$ optimal untuk pertumbuhan Lactobacillus bulgaricus dan Streptococcus thermophilus.

2. Melakukan uji organoleptik untuk mengetahui daya terima yogurt sinbiotik tanpa lemak.

3. Melakukan penelitian yogurt sinbiotik tanpa lemak dengan mengkombinasikan tepung pisang dan tepung gembili pada konsentrasi tertentu.

4. Melakukan pengenceran pada perlakuan dengan penambahan tepung pisang.

\section{DAFTAR PUSTAKA}

1. WHO. Cardiovascular disease. Fact sheet no. 317. WHO, Geneva, Switzerland 2009. Diunduh dari http://www.who.int/mediacentre/factsheets/fs317/e n/print.html.

2. Manson JE, Tosteson H, Ridker PM, Satterfield S, Herbert P, O'Connor GT, et al. The primary prevention of myocardial infarction. The New England Journal of Medicine 1992; 326 (21):14061416.

3. McNamara DJ, Lowell AM, Sabb JE. Effect of yogurt intake on plasma lipid and lipoprotein levels in normolipidemic males. Atherosclerosis, 1989;79: 167-171.

4. Standar Nasional Indonesia. Yogurt. ICS 67.100.10. SNI 2981:2009.

5. Food and Drug Administration. Yogurt. 21 CFR 131.200, Code of Federal Regulations. U. S. Dept. of Health and Human Services, Washington, DC. 1996.

6. Lambert JM, Bongers RS, de Vos WM, Kleerebezem M. Functional Analysis of Four Bile Salt Hydrolase and Penicillin Acylase Family Members in Lactobacillus plantarum WCFS1. Appl. Environ. Microbiol. 2008, 74, 4719-4726.

7. Schrezenmeir J, de Vrese M. Probiotics, prebiotics, and synbiotics - Approaching a definition. Am J Clin Nutr. 2001;73S:361S-364S.

8. Gibson GR, Probert HM, Van Loo J, Rastall RA \& Roberfroid M. Dietary modulation of the human colonic microbiota: updating the concept of prebiotics. Nutrition Research Reviews 2004;17, 259-275.

9. Jackson KG, Taylor GRL, Clohessy AM, Williams CM. The effect of the daily intake of inulin on fasting lipid, insulin and glucose concentrations in middle-aged men and women. $B r \quad J$ Nutr 1999;82:23-30.

10. Vigne JL, Lairon D, Borel P, Portugal H, Pauli AM, Hauton JC, Lafont $\mathrm{H}$. Effect of pectin, wheat 
bran and cellulose on serum lipids and lipoproteins in rats fed on a low- or high-fat diet. Br J Nutr 1987;58:405-413.

11. Trautwein EA, Rieckhoff D, Erbersdobler HF. Dietary Inulin Lowers Plasma Cholesterol and Triacylglycerol and Alters Biliary Bile Acid Profile in Hamsters. J. Nutr. 1998; 128, $1937-$ 1943.

12. Delzenne NM dan Kok NN. Effects of fructanstype prebiotics on lipid metabolism. Am. J. Clin. Nutr., 2001; 73, 456S-458S.

13. Beylot M., Effects of inulin-type fructans on lipid metabolism in man and in animal models. Br. J. Nutr., 2005; suppl., 1, S163-S168.

14. Campbell JM, Bauer LL, Fahey GC, Hogarth AJCL, Wolf BW, dan Hunter DE. Selected fructooligosaccharide (1-kestose, nystose, and $1 \mathrm{~F}$ fructofuranosylnystose) composition of foods and feeds. J. Agric. Food Chem. 1997;45:3076-3082.

15. Bouhnik Y, Achour L, Paineau D, Riottot M, Attar A, dan Bornet F. Four-week short chain fructooligosaccharides ingestion leads to increasing fecal bifidobacteria and cholesterol excretion in healthy elderly volunteers. Nutr. $J$ 2007; 6:42, doi:10.1186/1475-2891-6-42.

16. Roberfroid M. Dietary fiber, inulin, and oligofructose: a review comparing their physiological effects. Crit. Rev. Food Sci. Nutr. 1993;33: 103-148.

17. Cherbut, C. Inulin and oligofructose in the dietary fibre concept. British Journal of Nutrition 2002; 87, Suppl. 2, S159-S162. DOI: 10.1079/BJN2002532.

18. Boeni S, Purahmad R. Use of inulin and probiotic lactobacilli in symbiotic yogurt production. Scholar Research Library: Annals of Biological Research, 2012;3 (7):3486-3491. Diunduh dari www.scholarsresearchlibrary.com.

19. Winarti S, Harmayani E, dan Nurismanto R. Characteristic and inulin profil of wild yam (Dioscorea spp.). Agritech., 2011; Vol. 31, No. 4.

20. Davidson MH, Maki KC. Effects of dietary inulin on serum lipids. J. Nutr. 1999; 129, 1474S-1474S.

21. Winarti S, Harmayani E, dan Nurismanto R. Karakteristik dan profil inulin beberapa jenis uwi (Dioscorea spp.). Agritech., November 2011;Vol. 31, no. 4.

22. Boeni S. dan Pourahmad R. Use of inulin and probiotic lactobacilli in symbiotic yogurt production. Annals of Biological Research, 2012; 3 (7):3486-3491.

23. Hepner G, Fried R, Jeor SS, Fusetti L, dan Morin R. Hypocholesterolemic effect of yogurt and milk. The American Journal of Clinical Nutrition 32: January 1979, pp. 19-24.

24. McCleary BV, DeVries JW, Rader JI, Cohen G, Prosky L, Mugford DC, Champ M, dan Okuma K. Collaborative study report: Determination of insoluble, soluble, and total dietary fiber (codex definition) by an enzymatic-gravimetric method and liquid chromatography. AACC International Report, 2011; 56(6) : 238-247.

25. Ooi LG \& Liong MT. Cholesterol-lowering effect of probiotics and prebiotics: A review of in vivo and in vitro findings. Int. J. Mol. Sci. 2010, 11, 2499-2522; doi:10.3390/ijms11062499.

26. Winarti S, Harmayani E, dan Nurismanto R. Karakteristik dan profil inulin beberapa jenis uwi (Dioscorea spp.). Agritech., November 2011; 31(4).

27. Nadra MCM. Nitrogen metabolism in lactic acid bacteria from fruits: a review. Communicating Curent Research and Educational Topics and Trends in Applied Microbiology, 2007; 500-510.

28. Choo CL. Utilisation of matured green banana (Musa Paradisiaca var. Awak) flour and oat beta glucan as fibre ingredients in noodles. Universiti Sains Malaysia, 2007.

29. Wanasundera JPD dan Ravindran G. Nutritional assessment of yam (Dioscorea alata) tubers. Plant Foods for Human Nutrition, 1994; 46:33-39.

30. Gustaw W, Kordowska-Wiater M, dan Koziol J. The influence of selected prebiotics on the growth of lactic acid bacteria for bio-yogurt production. Acta Sci. Pol., Technol. Aliment. 2011; 10(4):455466.

31. Gustaw W, Wiater MK, dan Koziol J. The influence of selected prebiotics on the growth of lactic acid bacteria for bio-yoghurt production. Acta Sci. Pol., Technol. Aliment. 10(4) 2011, 455466.

32. Harti AS, Saptarini O, dan Lestari A. Kajian efek sinergistik probiotik (bakteri asam laktat) dan prebiotik (Maltodextrin 2\% dan Fruktooligosakarida 2\%) terhadap penurunan kadar kolesterol secara in vitro dan in vivo. STIkes Kusuma Husada Surakarta. 2001.

33. Boeni S. dan Pourahmad R. Use of inulin and probiotic lactobacilli in symbiotic yogurt production. Annals of Biological Research, 2012; 3 (7):3486-3491

34. Hui YH, editor. Handbook of food products manufacturing: health, meat, milk, poultry, seafood, and vegetables. New Jersey: John Wiley \& Sons, Inc.; 2007.

35. Hutkins RW dan Nannen NL. pH homeostatis in lactic acid bacteria. J. Dairy Sci. 1993;76:23542365.

36. Friend BA dan Shahani KM. Fermented dairy products. In: The Practice of Biotechnology: Current Comodity Products. New York: Pergamon Press; 1985.

37. Schrezenmeir J, de Vrese M. Probiotics, prebiotics, and synbiotics - Approaching a definition. Am J Clin Nutr. 2001;73S:361S-364S.

38. Lye HS, Rusul G, Liong MT. Removal of Cholesterol by Lactobacilli via Incorporation of 
and Conversion to Coprostanol. J. Dairy Sci. 2010; 93, 1383-1392.

39. Blaut M. Relationship of prebiotics and food to intestinal microflora. 7European Journal of Nutrition 2002;41:I/11-I/16 (Suppl 1).

40. Chen WJ, Anderson JW, dan Jennings D. Propionate mau mediate the hypocholesterolemic effects of certain soluble plant fibers in cholesterol-fed rats. Proc Soc Exp Biol Med 1984; 175:215-8.

41. Pan XD, Chen FQ, Wu TX, Tang HG, dan Zhao ZY. Prebiotic oligosaccharides change the concentrations of short-chain fatty acids and the microbial population of mouse bowel. J Zhejiang Univ Sci B, 2009; 10(4):258-263.

42. Winarti S, Harmayani E, Marsono Y, dan Pranoto Y. Effect of inulin isolated from lesser yam (Dioscorea esculenta) on the growth of probiotics bacteria and SCFA formation during fermentation. Int J Microbiology, Januari 2013; 4(2): 53-63.

43. Sapers GM dan Hicks KB. Inhibition of enzymatic browning in fruits and vegetables. Am. Chem. Soc., 1989; 405:29-43.

44. Singh U dan Bradbury JH. HPLC determination of vitamin A and vitamin D2 in South Pacific root. Journal of the Science of Food and Agriculture, 2006; 45(1) : 87-94.

45. Djurdjević JD, Maćej O, dan Jovanović S. The influence of investigated factors on viscosity of stirred yogurt. Journal of Agricultural Sciences, 2002; 47(2): 219-231.

46. Brenntag Food \& Nutrition Europe. Dietary fibers: technical and nutritional functionality. EFSA Journal 2010; 8(3):1462.

47. Isaac T, Arnold CJ, Whiting SJ, dan Dahl WJ. The effect of inulin-fortified thickened beverages on beverage acceptance, gastrointestinal function and calcium retention in dysphagic institutinalized young adults. Saskatoon District Health and College of Pharmacy and Nutrition, University of Saskatchewan, Saskatoon, Saskatchewan.

48. Moongngarm A. Chemical compositions and resistant starch content in starchy foods. American Journal of Agricultural and Biological Sciences, 2013; 8(2) : 107-113.

49. Augustin MA, Sanguansri P, dan Htoon A. Functional performance of a resistant starch ingredient modified using a microfluidiser. Food innovation: Emerging Science, Technologies and Applications (FIESTA) Conference, 2008; 9(2): 224-231.

50. Tester RF dan Morrison WR. Swelling and gelatinization of cereal starches: Effects of amylopectin, amylase, and lipids. Cereal Chem., 1990; 67(6): 551-557.

51. Lee WJ dan Lucey JA. Formation and physical properties of yogurt. Asian-Aust. J. Anim. Sci. 2010; 23(9): 1127-1136.
52. Donovan S, Stiefbold C, dan Sprague K. Chemical properties of amino acids and indentification of unknown amino acids. Association for Biology Laboratory Education, 1996. University of Oregon. 